\title{
Swiss Haemovigilance Data and Implementation of Measures for the Prevention of Transfusion Associated Acute Lung Injury (TRALI)
}

\author{
Markus Jutzi ${ }^{\mathrm{a}} \quad$ Guy Levy $^{\mathrm{b}} \quad$ Behrouz Mansouri Taleghanic,d \\ a Swissmedic (Haemovigilance), \\ ${ }^{b}$ Executive Board of the Blood Transfusion Service of the Swiss Red Cross, \\ ${ }^{\mathrm{c}}$ Regional Blood Transfusion Service of the Swiss Red Cross Berne LTD, \\ d Department of Hematology and Central Hematology Laboratory, Inselspital, University Hospital and University of Berne, Switzerland
}

\section{Key Words}

TRALI · Haemovigilance $\cdot$ Prevention · Transfusion risk

\section{Summary}

In Switzerland, blood donations are collected exclusively from healthy non-remunerated voluntary blood donors mainly by 13 regional Blood Transfusion Services throughout the country. Thereby, self-sufficient blood supply for a population of about 7.5 million is achieved, and approximately 300,000 units of red cells, 75,000 therapeutic units of fresh plasma, and 20,000 therapeutic units of platelets are transfused annually. Reporting to Swissmedic (the Swiss agency for therapeutic products) of all suspected adverse transfusion events on a standardised form is mandatory. Data are then analysed to estimate the risks of the most serious transfusion events. Together with transfusion of an incorrect blood component and bacterial contamination of platelet concentrates, TRALI is a significant risk of transfusion in Switzerland and occurs in approximately every 8,000-20,000 FFP transfusions according to current haemovigilance data. Among 25 reported cases between 2002 and November 2007, 4 are proven immune TRALI, 2 are highly likely immune TRALI, 10 are possibly immune TRALI, 8 are non-immune TRALI, and 1 is a suspected case which could not be confirmed as TRALI. Based on the hypothesis of an immunological trigger of TRALI, an exclusion of the transfusion of plasma from female donors can be considered as a precautionary measure which might have prevented 4 cases of proven immune TRALI, 2 cases of highly likely immune TRALI, and an unknown number of the 10 cases of possibly immune TRALI. Based on these data and encouraging preliminary reports of the effects of comparable measures in other countries, the decision was made that starting with January 1st 2007 the production of quarantined FFP is restricted to donations from men or from women confirming that they have never been pregnant (to their knowledge) or with negative tests for antibodies against HLA class I and II. The analysis of further vigilance data is needed to elucidate the efficacy of this preventive measure.

\author{
Schlüsselwörter \\ TRALI · Hämovigilanz · Prävention · Transfusionsrisiko
}

\section{Zusammenfassung}

In der Schweiz werden ausschließlich unentgeltliche Blutspenden von gesunden Freiwilligen, größtenteils in 13 regionalen Blutspendezentren, entnommen. Damit wird eine nationale Selbstversorgung mit Blutkomponenten sichergestellt, und es werden jährlich zirka 300.000 Erythrozytenkonzentrate, 75.000 therapeutische Einheiten Plasma und 20.000 therapeutische Einheiten Thrombozytenkonzentrate transfundiert. Alle vermuteten unerwünschten Transfusionsereignisse in der Schweiz müssen mit einem standardisierten Formular an Swissmedic (Schweizerische Überwachungsbehörde für Heilmittel und Medizinprodukte) gemeldet werden. Aufgrund der Analyse der eingegangenen Meldungen werden die aktuellen Risiken der schwerwiegendsten Transfusionsereignisse geschätzt. Neben der Transfusion falscher Blutkomponenten und der bakteriellen Kontamination von Thrombozytenkonzentraten stellt TRALI ein relevantes Risiko von Bluttransfusionen in der Schweiz dar. Aktuelle Haemovigilance Daten zeigen, dass eine TRALI in der Schweiz mit einer Häufigkeit von einem Fall auf ungefähr 8.00020.000 Transfusionen von FFP auftritt. Von 25 Fällen, die zwischen 2002 und November 2007 gemeldet wurden, sind 4 bewiesene, 2 sehr wahrscheinliche und 10 mögliche immunogene TRALI, während 8 als nicht immunogene TRALI beurteilt wurden. Ein vermuteter Fall konnte nicht als TRALI bestätigt werden. Basierend auf der Hypothese eines immunologischen Auslösers für eine TRALI kann die ausschließliche Transfusion von Plasma männlicher Spender als Präventionsmaßnahme in Betracht gezogen werden. Diese Maßnahme hätte wahrscheinlich die 4 gesicherten und 2 sehr wahrscheinlichen Fälle sowie möglicherweise eine unbekannte Anzahl der 10 Fälle von möglichen immunogenen TRALI verhindert. Aufgrund dieser Daten und ermutigender vorläufiger Berichte über die Auswirkungen vergleichbarer Maßnahmen in anderen Ländern wurde entschieden, ab dem 1. Januar 2007 zur Herstellung von quarantänisiertem FFP für die Transfusion in der Schweiz nur noch Spenden von Männern zu verwenden oder von Frauen, die bestätigen, nie schwanger gewesen zu sein oder negative Antikörper-Testergebnisse für HLA-Klasse I und II aufweisen. Die Analyse zukünftiger Hämovigilanzdaten ist erforderlich, um die Wirksamkeit dieser präventiven Maßnahme zu beurteilen.

\begin{tabular}{ll}
\hline KARGER & @ 2008 S. Karger GmbH, Freiburg \\
Fax +497614520714 & Accessible online at: \\
$\begin{array}{l}\text { E-mail Information@Karger.de } \\
\text { www.karger.com }\end{array}$ & www.karger.com/tmh
\end{tabular}

\section{KARGER}

www.karger.com
Dr. Markus Jutzi

Haemovigilance, Swissmedic, Swiss Agency or Therapeutic Products

Hallerstrasse 7, Postfach, CH-3000 Bern, Switzerland

Tel +41 31322 04-93, Fax -18

E-mail markus.jutzi@swissmedic.ch 


\section{Introduction}

Switzerland has a population of about 7.5 million. Approximately 300,000 units of red cells, 75,000 units of plasma $(60,000$ units of quarantine fresh frozen plasma (qFFP) and 15,000 units of solvent-detergent plasma (SD-P)) and 20,000 therapeutic units of platelets have been transfused in 2006. Currently, there are no mandatory national transfusion guidelines in Switzerland. The Blood Transfusion Service of the Swiss Red Cross Ltd (BTS SRC), a non-profit organisation, is in charge of the reference activities in immunohaemotology and serology, and issues the national guidelines that regulate the standards of quality and logistics for blood donations. Blood donations are collected exclusively from healthy non-remunerated voluntary blood donors mainly by 13 Regional Blood Transfusion Services (RBTS) throughout the country. Thereby, self-sufficient blood supply is achieved. In 2002, the federal Law on Therapeutic Products was enacted. The law set up a federal drug regulatory agency (Swissmedic) which is the competent authority for blood components. The decisions of Swissmedic are mandatory all over the country and guarantee the quality, safety, and efficiency in preparing and releasing blood components. RBTS and all hospitals performing blood transfusions must nominate a person in charge of haemovigilance who notifies all suspected adverse events to Swissmedic.

\section{Data Collection and Analysis}

All suspected adverse events have to be reported to Swissmedic using a standardised form. Reported events are categorised according to criteria defined in the annual national report of 2002/3 [1]. The collected data are analysed annually and summarised in a national haemovigilance report. For the current analysis of the cases of TRALI, the recent definition of the Consensus Conference of Toronto is applied [2]. Based on these data, the number of annually transfused blood components and international haemovigilance data, we estimated the possible degree of underreporting and the risk for significant adverse events.

\section{Results}

The reported suspected adverse transfusion events in 2005 and 2006 are sorted by declining incidence of categories and summarised in table 1. Bacterial contamination of platelet concentrates are included in the category of 'Transfusion Transmitted Infections'. The 8 and 4 notifications of clinically significant bacterial contamination of platelet concentrates in 2005 and 2006 , respectively, result in an estimated corresponding risk of transfusion transmitted bacterial infections of at least 1:2,500 to $1: 5,000$. The risk of administration of an incorrect blood product is estimated at 1:20,000 transfusions. Three and 8
Table 1. Number of reported suspected Transfusion Events in Switzerland by category

\begin{tabular}{lcc}
\hline \multirow{2}{*}{ Category } & \multicolumn{2}{l}{ Patients, $\mathrm{n}(\%)$} \\
\cline { 2 - 3 } & 2005 & 2006 \\
\hline Febrile non-haemolytic transfusion reaction & & \\
$\quad$ (FNHTR) & $188(30.5)$ & $246(31)$ \\
Allergic transfusion reaction & $115(19)$ & $157(20)$ \\
Near miss event & $97(16)$ & $135(17)$ \\
Development of allo-antibody & $66(10.5$ & $108(13.5)$ \\
Transfusion associated circulatory overload & & \\
$\quad$ & $26(4)$ & $26(3.5)$ \\
Incorrect blood product transfused (IBPT) & $21(3.5)$ & $18(2.5)$ \\
Haemolytic transfusion reaction (HTR) & $12(2)$ & $12(1.5)$ \\
Transfusion transmitted infection & $12(2)$ & $9(1)$ \\
Hypotensive transfusion reaction & $9(1.5)$ & $10(1.5)$ \\
Event not related to transfusion & $6(1)$ & $21(2.5)$ \\
TRALI & $3(0.5)$ & $10(1.5)$ \\
Hyperkalaemia & $0(0)$ & $1(0)$ \\
Other events & $59(9.5)$ & $37(4.5)$ \\
Total & $614(100)$ & $790(100)$ \\
\hline
\end{tabular}

cases of suspected TRALI were reported in 2005 and 2006, respectively, after administration of qFFP. Another 2 cases of TRALI were reported in 2006 after administration of red blood cells only. Since approximately 60,000 qFFP are administered in Switzerland annually, the risk of TRALI can be estimated at 1:8,000 to 1:20,000 after administration of 1 unit of qFFP.

\section{Discussion}

As reported by Michlig et al. [3], an adverse transfusion event is expected after almost 5 of 1,000 transfusions. In comparison with the reported 1.5 and 2 suspected adverse transfusion events per 1,000 transfusions prescribed in Switzerland in 2005 and 2006, respectively, one can assume a significant underreporting.

Bacterial contamination of platelet concentrates, transfusion of an incorrect blood component and TRALI are considered to be the most serious adverse events $[4,5]$. The estimated risks for transfusion of a bacterially contaminated platelet concentrate, TRALI due to plasma transfusion and transfusion of an incorrect blood component are 1:2,500 to 1:5,000, $1: 8,000$ to $1: 20,000$ and $1: 20,000$, respectively. For the period of 2002-2004, the risk of a transfusion transmitted viral infection was estimated at 1:2,300,000 for HIV, 1:2,200,0000 for HCV and 1:141,000 for HBV [6].

Consequently, we conclude that current haemovigilance data support the assumption that TRALI is a significant transfusion risk in Switzerland. Our analysis of TRALI data collected in Switzerland between January 2002 and November 2007 reveal that cases can be attributed to groups supporting both, the immunological hypothesis [7] and the two-hit model [8]. 
Table 2. TRALI cases and their etiologic category

\begin{tabular}{|c|c|c|c|c|c|}
\hline $\begin{array}{l}\text { Year / case } \\
\text { number }\end{array}$ & $\begin{array}{l}\text { Product(s) } \\
\text { involved }\end{array}$ & Antibody specificity & $\begin{array}{l}\text { Corresponding } \\
\text { antigen in the } \\
\text { patient }\end{array}$ & Category $^{\mathrm{b}}$ & Category of TRALI \\
\hline $2002 / 1$ & FFP & HLA-I & n.t. & 3 & possibly immune \\
\hline $2003 / 2$ & PLT & HNA-2a & n.t. & 2 & highly likely immune \\
\hline $2003 / 3$ & FFP & HLA-I & yes & 1 & proven immune \\
\hline $2003 / 4$ & FFP PLT RBC & none & n.t. & 4 & non-immune \\
\hline $2004 / 5$ & FFP & HLA-I, HLA-II & n.t. & 3 & possibly immune \\
\hline $2004 / 6$ & FFP & HLA-I & n.t. & 3 & possibly immune \\
\hline $2004 / 7$ & $\mathrm{RBC}$ & HLA-II & n.t. & 5 & non-immune \\
\hline $2004 / 8$ & FFP & HLA-A2 & n.t. & 3 & possibly immune \\
\hline $2005 / 9$ & FFP & HNA-2a & n.t. & 2 & highly likely immune \\
\hline $2005 / 10$ & RBC FFP & none & n.t. & 4 & non-immune \\
\hline $2005 / 11$ & FFP & HLA-DR7 & yes & 1 & proven immune \\
\hline $2006 / 12$ & FFP & HLA-I, HLA-II & n.t. & 3 & possibly immune \\
\hline $2006 / 13$ & FFP & HLA-II, anti-DR52 & yes & 1 & proven immune \\
\hline $2006 / 14$ & FFP & none & & 4 & non-immune \\
\hline $2006 / 15$ & FFP & HLA-II, anti-DR52 & & 3 & possibly immune \\
\hline $2006 / 16$ & FFP & HLA-I and HLA-II & & 3 & possibly immune \\
\hline $2006 / 17$ & FFP & HLA-II, anti-DR52 & yes & 1 & proven immune \\
\hline $2006 / 18$ & RBC FFP & anti HLA-I & n.t. & 3 & possibly immune \\
\hline $2006 / 19$ & RBC FFP & anti-granulocyte not specified & n.t. & 3 & possibly immune \\
\hline $2006 / 20$ & RBC FFP & negative & & 4 & non-immune \\
\hline $2006 / 21$ & FFP & HLA II & n.t. & 3 & possibly immune \\
\hline $2007 / 22$ & FFP & negative & & 4 & non-immune \\
\hline $2007 / 23$ & $\mathrm{RBC}$ & negative & & 4 & non-immune \\
\hline $2007 / 24$ & $\mathrm{RBC}$ & negative & & 4 & non-immune \\
\hline $2007 / 25$ & RBC and FFP & & & 6 & no TRALI \\
\hline
\end{tabular}

$\mathrm{RBC}=$ Red blood cell concentrate $; \mathrm{FFP}=$ fresh frozen plasma PLT = platelet concentrate HLA = human leukocyte antigen; HNA = human neutrophil antigen; n.t. = tested.

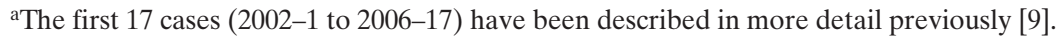

$\left.{ }^{b} 1\right)$ These cases were considered proven immune TRALI due to antibodies against HNA and/or HLA antigens present in the donors serum and the corresponding antigen and/or a positive cross-match on/with patient cells; 2) These cases were considered highly likely immune TRALI based on detected antibodies against HNA antigen (HNA-2a) in the donors serum and the fact that products (1 PLT and 1 FFP) of this donor were involved in 2 TRALI cases with classical clinical presentation. No antigen determination for the patients are available; 3) Possible immune TRALI due to the following constellation: clinical presentation and course compatible with TRALI, antibodies against HNA and/or HLA antigens present in donors serum, corresponding antigen and/or cross-match in/with patient cells negative or not available; 4) TRALI and no detectable antibodies in the donors (classified as non-immune TRALI); 5) In this case, clinical TRALI occurred after transfusion of a 13 day old RBC. Antibodies against HLA II (DRw 52 and DR 8) were detected in the donor. Neither the cross-match test nor the antigen determination in the recipient has been performed. Because of the small quantity and specifity of antibodies present in an RBC, this case was considered to be most likely a non-immune TRALI, even though immune TRALI may also be considered; 6) This case was reported to Swissmedic as suspected TRALI and - after the investigations had been completed - could not be confirmed as TRALI.
Among 25 reported cases, 4 are proven immune TRALI, 2 are highly likely immune TRALI, 10 are possibly immune TRALI, 8 are non-immune TRALI and 1 is a suspected case which could not be confirmed as TRALI. The cases are summarised in table 2. Seventeen of these cases were reported between 2002 and June 2006 and have already been published [9]. The additional 8 cases were reported to Swissmedic between June 2006 and November 2007. Based on the hypothesis of an immunological trigger of TRALI, an exclusion of the transfusion of plasma from female donors can be considered as a precautionary measure. The introduction of such a measure might have prevented 4 cases of proven immune TRALI, 2 cases of highly likely immune TRALI, and an unknown number of the 10 possibly immune TRALI, but would most likely have had no influence on the 8 non-immune TRALI cases.

Prompted by the encouraging effects of comparable measures in other countries, in 2006 the BTS SRC managed a national study in order to determine whether the supply of qFFP could be reliably maintained by collecting plasma from male donors only. The study confirmed this assumption, given the fact that $80 \%$ of the required plasma for transfusion was covered by qFFP and $20 \%$ by SD-P. Provided that these proportions are maintained, the decision was made that starting January 1, 2007 the production of qFFP is restricted to donations from men or from women confirming that they have never been 
pregnant (to their knowledge) or with negative tests for antibodies against HLA class I and II. Plasma donated before the introduction of this measure may still be released for transfusion until the end of 2009. Therefore, our current haemovigilance data do not yet allow any conclusions on the efficacy of the measure introduced. In this context, it has to be mentioned that all persons who have been transfused after 1980 are already definitively deferred from donating blood since October 1,2004 , primarily as a precautionary measure to prevent the possible transmission of variant Creutzfeldt-Jakob disease (vCJD) through blood components.

\section{References}

1 Swissmedic: Hämovigilanz Bericht 2002/2003; www. swissmedic.ch/files/pdf/Haemovigilance_Jahresberic ht_D.pdf.

2 Kleinman S, Caulfield T, Chan P, et al.: Toward an understanding of transfusion-related acute lung injury: statement of a consensus panel. Transfusion 2004;44:1774-89.

3 Michlig C, Vu D-H, Wasserfallen J-B, Spahn DR, Schneider P, Tissot J-D: Three years of hemovigilance in a general university hospital. Transfus Med 2003;13:63-73.
4 SHOT Annual Report 2006, p. 13; www.shotuk.org/ SHOT_report_2006.pdf.

5 Davis A, Mandal R, Johnson M, Makar R, Stowell C, Dzik S: A touch of TRALI. Transfusion 2008:48: $541-5$.

6 Niederhauser C, Schneider P, Fopp M, Ruefer A, Lévy G: Incidence of viral markers and evaluation of the estimated risk in the Swiss blood donor population from 1996 to 2003. Euro Surveill 2005;10: 14-6.
7 Bux J, Sachs UJ: The pathogenesis of transfusionrelated acute lung injury (TRALI). Br J Haematol 2007;136:788-99.

8 Silliman C: The two-event model of transfusion-re lated acute lung injury. Crit Care Med 2006;34: S124-31.

9 Senn M, Mansouri Taleghani B: International forum: measures to prevent TRALI. Vox Sang 2007;92:258-277. 